\section{artelogie}

\section{Artelogie}

Recherche sur les arts, le patrimoine et la littérature de l'Amérique latine

$15 \mid 2020$

Latin American networks: Synchronicities, Contacts and Divergences.

\title{
Translate the impenetrable. Conversation with Julieta Hanono
}

\section{Andrea Giunta}

Translator. Beatriz Vignoli

\section{(2) OpenEdition \\ Journals}

\section{Electronic version}

URL: http://journals.openedition.org/artelogie/4487

DOI: $10.4000 /$ artelogie.4487

ISSN: 2115-6395

\section{Publisher}

Association ESCAL

\section{Electronic reference}

Andrea Giunta, «Translate the impenetrable. Conversation with Julieta Hanono », Artelogie [Online],

15 | 2020, Online since 17 April 2020, connection on 05 August 2020. URL : http:// journals.openedition.org/artelogie/4487

This text was automatically generated on 5 August 2020

Association ESCAL 


\title{
Translate the impenetrable. Conversation with Julieta Hanono
}

\author{
Andrea Giunta \\ Translation : Beatriz Vignoli
}

1 This interview with artist Julieta Hanono was conducted in 2019 on the occasion of her exhibition Traducir la impenetrable (Translate the Impenetrable) at the Museo de la Cárcova in Buenos Aires. Julieta was born in Rosario, Argentina, and lives in Paris. As an adolescent, she was arrested-disappeared by Argentine military forces during the dictatorship. She studied art and philosophy first in Argentina and then in France. Her film $E l$ pozo (The Ditch) addresses her experience in prison. Her recent work has focused on the problem of translation.

2 The show at the Museo de la Cárcova brings together a collection of reproductions of antique and classic works on which Hanono intervened. She drew on the museum's floor, rendering amidst its sculptures and pedestals a network of names of Latin American women poets connected by lines in the colors purple (feminism's historical color), green (the color of the campaign to legalize abortion in Argentina), and orange (the color of the campaign to separate the Catholic Church and the State). With its network of names and lines, Cosmología de las poetas (Cosmology of the Poets, 2018-2020) runs through the entire museum space. In another gallery, La riqueza de las naciones (The Wealth of Nations, 2016, MALBA collection), a dual-channel video, is screened. One channel shows the sun setting over Iguazu Falls, and the other a fragment Adam Smith's The Wealth of Nations. The installation proposes a critical reflection on the thinking of the Scottish economist and philosopher and on his analysis of how wealth is constituted.

3 Traducir la impenetrable includes the work the artist produced in collaboration with members of the Qom community originally from El Impenetrable, a region in Chaco province, but who now live in Rouillón on the outskirts of the city of Rosario. Her interlocutors in the community are Arsenio, who makes clay animals, and Ruperta, who took plant species with her when she moved from 
Chaco to Rosario. The multitude of small animals in Animalitos / La manada (Little Animals/The Herd, 2018) refers to the idea of diaspora. There are as many animals as there are kilometers between Buenos Aires and Resistencia: nine hundred and thirty-five. The exhibition includes as well El jardín mágico de Ruperta (Ruperta's Magical Garden, 2019), the herbarium that Julieta put together with prints of the plants Ruperta gave her from her garden. The prints on overlapping sheets of translucent vegetable paper create a delicate visual texture. Hanging in another gallery is Una capucha de nubes (A Hood of Clouds, 2013-present), a series of white-on-white prints of a text in which Julieta captures her experience of living between two languages, Spanish and French. This version of the work includes a translation into Qom by Arsenio. The work addresses diasporia-both the Qom community's and the artist's, as her life bridges Paris, Buenos Aires, and Rosario.

\section{Andrea Giunta}

You were trained in engraving, you made an embroidery piece (almost a loving suture work), then you began making photo and video art, and in recent years you have been expanding your languages to poetry and translation. Could you explain these choices? What causes such free flowing coexistence among languages? Have you found one permanent language, or what defines you is precisely such migration among spoken or written word, its doubles (translations) and the countless existing techniques for image capturing?

such migrations may perhaps be called skin changeovers, just like snakes do, anacondas in Paraná River in particular, who I love so much, they shed their skin and remain the same yet they change, because, just like them, I shed my place of residence and language

leaving Argentina meant for me to leave a language that was so close to my body (my mother tongue, the one spoken by my mother) that left me stuck in affection so I could say nothing, because everything was so thick, I could not find myself in a space with just enough room for the exact solitude of my being, so as to weld together my own weapons, what we can call a language, a new alphabet

meeting another language is something I experience as a revolution, a sea change around the axis of myself, I had to de-construct myself (in Derrida's terms), and by pushing even further I may look like a cosmonaut entering a black hole event horizon and coming out through on the other side, being at once myself and someone else,

techniques to me are intimately related to what one needs to say, serving an intimate need, engraving technique, dry point in particular, carries within it an inscription gesture, it is analogous to writing, it is a way of writing which emphasizes the pressure exerted by the hand over the matter, over the copper plate or the tin plate, when learning to write as a child, I remember I drew sticks first, and... writing is harmful at first, it is like learning to play guitar, fingers holding hard on to the pencil pressed against the paper sheet... there's a similar feeling to dry point, which is by no means meaninglessly the first technique I employed

11 photography was what I needed in order to delve into myself, which I couldn't do otherwise, I needed an image to get me closer to the most real and to depart from 
metaphor, from storytelling, from the gesture of my own hand, which I had already performed both in drawing and painting,

photography catches [images], and it does it in an immediate way (since the camera I used was a digital one that takes pictures and displays them onscreen instantly), and later on those images were worked over so as to cool them down and push them even farther away,

13 I made photographs with a speculum inserted into my own sex, because I wanted to speak about the inside of my body which was home to my future child, and the speculum was a magnifying glass and a keyhole to peep and see through at once, so I made a mysterious place my own, while at the same time I was telling the story of my mother's cave and maybe, from a certain locus, the story of my mother tongue,

I was able to come back down into the pit, shielded behind a camcorder (like Perseus's mirror), at el pozo, the clandestine detention center in Rosario where I was detained since 1977 through 1979; video technique was able to capture my body in there, it was able to record the present I would say, my uneasiness, my fear, my awe at returning,

I came down rigged, sheltered by the camera which is like another eye (it is by no means meaningless to film in a place where time sits still, it is to put in motion what has been frozen, detained), the experience of touching the real was fundamental for all my work,

as it was so difficult, almost impossible to convey it in images, since there were no images to speak the unspeakable, I decided to name all that disappearance with new words, words that came from that other tongue, French language, which had given me the chance to distance myself,

17 I started to write, not translating but babbling, as if learning to speak, and in the process of such eventually oscillating exercise (for I dream both in Spanish and French), by writing in that new tongue, I would return home to my old self, however standing in a different place already, and creating an in-between languages as well, which meant my nowhereness

18 I cannot say my language is permanent but I shall certainly call permanent this oscillation between one place and the other, this I understood through the exercise of writing, such dialectical swing showed a way for myself to be my own self, how it took to shed my skin and tongue for me to pull myself apart from the presence of a past always too close, a real such as having witnessed, at 16 , the inhumanity of a clandestine detention center, having touched it with my very own being and having come out

For many -including myself - it can be traumatizing to depart from one's mother tongue. Maybe because I lived abroad in the States when I was older than you were when you left for France, it meant an uneasy displacement, it felt joyless for me. Such is the experience many expatriates have. To you, however, it became a creative circumstance, which pulled the best out of you. Was it because you drifted away from your mother tongue to become the mother tongue of your children? Anyhow, you created a host of visual and sound devices (the rhythm of oral poetry-word) that led you to what you call a revolution. Which specific conditions do you think were provided by the fact that the new language was French? How familiar were you with that language? Do you think another language would have caused the same experience in you? 
20 I left thinking I would not miss anything, I tore my way back ticket apart, just like someone who leaves a house slams the front door and throws away the key, you are right, the experience of departing from a language is painful, it always leaves a huge emptiness inside, what you tell me about your own experience resounds in me, I think we all immigrants must grieve for our mother tongue, not just for our mother tongue but grieve as well for that landscape we might call childhood arriving at Paris was not just fleeing from something, it was an encounter with another culture with its possibilities and boundaries, it meant jumping through the mirror, from Paris I saw myself, not just as an Argentinean, I understood myself as South American, it took a journey North for me to know I vibrate from the South, in another location, with a different energy vibe as I left I believed (as deeply as one can hold on to a supernatural, soul-saving belief) that ghosts from the past should vanish and yet they came back stronger, dematerialized like ruins emerging amidst a new, strange landscape,

but this isolation condition of being aware I was a fish out of another water proved to me I was not a fish in water in my mother tongue either, and so my departure meant my understanding of how the singularity of a gaze of our own dooms us to always being foreigners

Paris bestowed on me such cruel, soul-saving evidence, which triggered my creation, as a lightening space we may call poetry, a singular locus of being, a point of solitude, making us unique and to a certain extent untranslatable

it was that tongue which allowed me to shatter my personal myths, my comfort zones, my charming twitches, building instead my own ground as my steps walked it, and so it dawned on me that what I call art is a consequence of unfolding my earliest ideas, my earliest emotions as a little girl, from my deepest intimacy, displaced already from grammars which are spoken by the other, since another tongue helps one to depart from what Lacan calls the parlêtre (the fact of being spoken by anyone else) and this is how one, by babbling, learns to listen to oneself

although I was lonely in the prison I was not alone, for you're never alone when your chasers are lurking around; Paris forced me to see, to touch things with my eyes, in Paris I was able to touch what I had always seen in tiny pictures, to see Philippe de Champaigne's brushstroke, the folds of last supper's tablecloth, crimson grays on cardinal Richelieu's drooping cloak, I dived into Monet's water lilies and saw a circular city out of reflection, both suffocating me in its harshness and at once pushing me out, flying, up an ascending spiral

when I arrived a gay friend of mine took me to hospital and I got tested for aids, kindly amazed because it was anonymous and for free, and later on, when I was already married and mother to my first child, I aborted; I did it at a state hospital too, there is no such thing as paradise, but it's true that certain specifically female issues were solved beforehand for me when I got there,

in Buenos Aires I had read Simone de Beauvoir's The Third Sex (sic), and although patriarchal standpoints are present in every society and exerted behind different masks, this new context made me more self-confident and helped me untangle actual fears, tied to dramatic moments of my life in my homeland

Paris, French tongue gave me wings, wings to fly above myself and be aware that my political activism as a young woman is always present and is now embodied in other 
languages, enabling me to come up with new visual, poetic and I may add aural solutions, now that you ask me, for my writing is a double play of words and sounds,

my art projects today, I make them by meeting other people, who belong to various disciplines, who teach me how to speak their other tongues, creating projects that grow beyond me and at the end of the day are economical, political, sentimental productions so how to inscribe a new tongue in my children's language, they grew in both, I would sing them lullabies between my two, the French I speak is a foreigner's, they have been cradled by my accent, they are crossbreeds, being a mother is to depart from one's mother body's tongue so as to create one's own

Let's go back to El Pozo. Why did you decide to return to the place where you had been held imprisoned? When you returned in there with the camera, was it the first time you were there as a visitor?

it was not a decision I gave much thinking to, it was rather of an intuitive kind, I came back down to el Pozo as an archeologist wishing to find forceful objects that were proof of her idea about the remnants of the past, a past that was vividly alive within myself, resounding as I said in a ghostly echo, chasing me in Paris, preventing me to return to Argentina, such an abyss of losses,

it took me to get inside my body through photographs of my own sex and the speculum peeping into it, in order to later be able to get inside my prison, I might have been able to do so because I could depart from the tongue that contained and restrained me, keeping me locked in the imaginary locus of my mother's womb, and I could release myself from her shelter, free at last when out of my infant body I became more than just a daughter making this choice, an unpremeditated one as I already said, meant jumping backwards, entering the cave of el Pozo just like someone who enters the grotto of her mother, it was almost like returning from nothingness, from the very nothingness we come from

it was a true initiation journey, touching el Pozo was to touch the real, what belongs to the category of unthinkable, what comes before words, for it is unspeakable, the sheer violence of what Giorgio Agamben would name as an exception state; I saw what I had never fathomed I would see and I had to make something out of it, for it clotted within me and blocked my life, I wished I was able to tell it to myself, maybe that was the way, so I could tell it to everyone else,

there were objective issues involved, a change in government, a more open policy in human rights' affairs when I made an installation there, we opened it up to neighbors and did it along mothers' and sons' associations

the first time I came down in, I was already furnished with the camera, I remember the previous night I became very sick, so powerful it was to return there knowing I was now standing on the other side, testing with my own very body such catastrophe beyond repair, and the place felt smaller to me

\section{Could you describe El Pozo's film sequence and how it's organized?}

40 I actually filmed a lot, walked through the whole space, always behind the camera's eye, later on I chose certain sequences that seemed to, rather than illustrating the place, displace it from storytelling and reveal its structure 

beautiful definition, it was a healing gesture indeed, asking those women to stay by my side back in time to those days of despair, to surround me, to hold me, with their embroidering hands, because the 395 embroidery pieces those women made stand for my 395 days spent in captivity,

51 it was also mom this time who gave me white cloth and color threads, for me to make myself a dress so I could nourish hope, so I could think there would be a day when I shall be released, dressed in my dress, the experience of 395 project production with the other journey, the one I make to the heart of my past in my mother tongue, they overlap with each other, both stories leaking into one another, their timelines mutually interfering; what was before 
becomes what shall be afterwards, everything keeps coalescing into the now, French language enounces while the other language, the one from Argentina, enounces differently

53 I wrote 4 pages and went on to 40; I had the enormous privilege that my first reader, already beyond my intimate circle, was Martinican poet and intellectual Édouard Glissant, the father to the concept of creolization

I showed him my manuscript, I was so uneasy, he lived in a big apartment at Invalides; time had flown past him, he was already weary but stood together, this beautiful, black, sturdy giant, smiling like a mischievous kid

he asked me to number the pages, read them one by one as he got amused by my spelling mistakes, mistakes that were invisible to me, and still are, and he told me: it's very good this way, he corrected some of them, left some as they were, and this is how I began to write

It was easier for me to understand words, or rather ideas, from the other language; I was able to forget so as to remember and stand therefore as one who looks at herself, a storyteller for a story of temps mêlés, mixed up times

Your account about your interstitial situation as regards language is very interesting. They say translating also means betraying. And this in fact occurs in your artwork, where words may be beyond standard written language, and languages get mixed up and transformed. Does this interstitial metaphor work with your process of being in-between?

58 yes, that's right, there is some sort of betrayal, but I would wonder who is betrayed, language? language speaker (its subject)? or certain attachement (the word comes out in French) the word translates [for me] to bonding, it happens to me sometimes that I find myself thinking in-between one language and the other, and I may betray, I may forget the other language

59 from the viewpoint of my way of writing I would say I betray my past, and more precisely, the way I conceive my language as it was taught to me, that language that was learnt by me in my school years

60 Freud in a superb statement defines the unconscious, naming it as navel of the whirlwind of dreams; maybe my relation to translation, conceives some sort of betrayal to the blood ties, to what binds me to my mother tongue

61 ....and as $i$ oscillate between one tongue and the other, in between two languages, in between inside and out, $i$ untie myself, $i$ disentangle my knots...

62 Shuar aborigines in the Amazon jungle say life as we modern western people understand it is not real life; reality is to them what they experience under the influence of hallucinogenic drugs, powerful substances they extract from plants and from roots

even further on over the fact that every relationship with anyone else implies a translation, because the discourse I enounce shall resound differently to the listener's, every subject carries along his or her own language, the matrix hallmark of a history that was hatched before one's birth, so in order to become receptive we may always need to betray our earliest writing

and isn't poetry a betrayal against language, a glowing flash, building upon a pure invention? 

How is your interplay between languages?

such a sway in-between tongues may seem like swinging in a swing, a game cradled by two until it starts, one of them pushing her own weight away from the ground with the tip of her feet, catching momentum, staying in the air, flying over, just like someone who revisits a place that is always new, for as you come and go, something unexpected is produced

a more distant gaze, one allowing us to be able to pin down things with their names, in one's own way, and displaying them that way in front of the world, shall be like being a hinge holding that door that open that closes and sways between one place and the other,

a hinge keeps doors together as they open and close, it's a thing with that function, $i$ see my gesture inscribed in the air, mi spread arm illustrating the word, with my twisted hand i'm receding, this is not a handle nor my wrist, it's a screwdriver

between two tongues, it's a play between two hemispheres, to acknowledge myself as South American, to walk a tight rope between North and South, without relinquishing my foreign woman accent, forever a travelling she-passenger (as Charly García would say: pasajera en tránsito) and keeping as a treasure my amazement which equals my ability to keep learning, being Alice, always passing through the looking-glass

\section{Which is your original language and which is the one you adopted?}

the original one is the tongue that spoke to me even before I had my own voice, the one that cradled me when I was inside my mother's womb, the matrix, the one I learnt to write by first drawing sticks

the adopted one is the language that receives me and the one I found, it's the one I had to learn as I got rid of my tics involved in the other one; I learned it by myself, by trialand-error, playing blind man's buff, building from scratch its irrigation systems, going through my somewhere else's citizen paperwork, deep into foreign administration and laws, hitting my head against its foreign codes,

73 I held on hard to my new language, just like someone who hangs on to her last resort; I met French, and that meant a widening of my field of vision, just like someone who switches to wide-angle lens for her camera, I was able to zoom out enough distance and retrieve my $(\mathrm{m})$ other tongue, so as to be able to utter my earliest language, from my own subjective uniqueness

4 Do you dream in both languages, but still recognizing the difference between them?

5 I dream in both, it's when I'm waking up, when I float back to the surface, a phrase or a word emerging

I'm writing to you in Spanish now, right now I'm thinking with my earliest language, already tinged by the other one, I feel so easy writing in Spanish, it would not be so easy if I did it in French; but as I reread myself I can testify my writing style, crossed over already with the other language,

I write differently because I think differently, travelling between both languages provides me with an isolation space and I might increase in lightness, to unfold myself along a dual writing is to live a resonance, because another language is neither an echo nor a shadow, I'm speaking in one (but the other one is listening), it's a meeting spot, a company, that nowhere in-between two, 
Homi Bhabha figures mimicry as a relation between colonizer's language and the language of the colonized, the subordinate subject. This has to do with a strategy, in a sense, of survival in the face of power. Do you find any echo of this relation in your experience [of living] in France, a country that waged a bloody war against one of its colonies, Algeria, to give just one example? How do you negotiate your aesthetic and affective standpoint in that network of relations?

mimicking French language would mean to follow its rules by the book, but I depart from it, the gesture of leaving as it is certain spelling mistakes and semantic errors is not just poetical but political as well

all along the development of my work, from my texts presented as fragments, testimonies, figments of dreams, self-referential literature, spoken in first person singular, to their translation into different languages and techniques,

my starting-point reference is my work with Mexican embroiderers, when they followed the pattern I provided them and translated, each in her own unique fashion, an object that was embroidered their way in the first place

2 I think of my text Ils, translated by maestro Arsenio to his mother tongue, Qom, as he does he says he feels he becomes female, he becomes a woman so as to be spoken through and stand in place of what speaks,

I insist translation is not linear, every text is equivalent, one does not translate the other, there is no subjection of my Argentine writing to writing in French,

the horrors of the war in Algeria are especially pertinent to us South Americans; today we know that the torture methods French military men used to massacre their opponents in the war against the Algerian independence were imported, with United States support, by the infamous Cóndor operation

model counters itself in its own field, critical conversation partners emerge from colonial language itself, opposing the master in his own language, I'm thinking about Frantz Fanon and his enlightening essays

standing between South and North implies a distance from my mother tongue, it unravels me, it becomes a spot from where to put into question the colonial and patronizing position, and at the end of the day this is how my artistic practice unfolds,

my in-between-two hangs together with the concept of creolization Édouard Glissant invented, thinking that if the slave (in Hegel's terms) frees himself of oppression, no longer being spoken by the master's orders voice, he shall create his own language, one aware of his past under enslavement, and such new language shall be his liberation,

this standpoint, woman, immigrant, out from a gaze that looks from South to North, I write as I speak, with my accent, I think out from this accent, I become crossbred, contaminated; I speak and am spoken from the language of insubordination

In your art show at the de la Cárcova Cast Museum (Museo de Calcos de la Cárcova) you'll be exhibiting new artworks, some finished, and some in progress. These works shall intervene and be placed among the stately cast collection, which reproduces milestones in the history of Western art and prehispanic art as well. We stood there figuring out how your projects should be displayed. We have anticipated the instances of dialogue and friction that might arise, which we may think about [again] once the exhibition is installed, as a coda to this text. Right now, I would just discuss specifically your works. The exhibition is tentatively 
titled Traducir la impenetrable. We have already extensively considered the importance you give to language and translation, as well as their gaps, minor instances of incorrectness, punctures in language caused by the coming and going from one tongue to another, symptoms manifested as grammar deviations from the standards of written language, perceived by the reader as slight malfunctions with a meaning he or she however understands. It is pleasant to get immersed in the out-of-joint but intelligible tone of your writing. Let's begin with the title, Traducir la impenetrable. I've checked the dictionary and found out that the actual name of such 15445 square mile native woodland in the province of chaco $(40.000 \mathrm{~km} 2)$ is "el" impenetrable. Why female?

for years now I have giving my shows titles beginning with the word translation, which I write at the beginning of a phrase, the word translation as a verb becomes an action, it shall mean to bring, to show, to tell to my own language, and as you well write it, it involves playing some sort of game, one where error has a function as a Freudian slip breaking the lock of censorship, building an utopian possibility

91 I thought, among other things, about a work by Jesús Rafael Soto, Penetrables (vertical lines suspended at a certain height forming a rectangular or cubic shape, where the audiences are invited to step in) people wander into that jungle of lines, but they are straight lines, where no one can get entangled

Qom community comes from a different place, a thick forest, a wilderness, one almost impossible to walk into unless one was born there, that is why it's called impenetrable,

Qom land is a womb, mother earth, pacha mama (honored by Ruperta as well as by Arsenio) and to make it become female, naming it from a female article, means to charge this space with power, female article -la- ahead transforms it back into that impenetrable spot, a safe shelter

-la- refreshes its meaning, it's a political feminist standpoint, translating la impenetrable means to restore land its earliest properties, cutting the barbed wires, setting it free, translating la impenetrable means an untranslatable wild vitality, it means to translate wilderness, the female, the subversive, she-shamans, witches, the snakes that change their skin over as if it were a dress, an unwritten language, nomadic, flowing, elusive, climbing as untamable as vine

if the female is mystery, the mysterious is not penetrable, into mystery we are initiated, in order to understanding it we need to put down our weapons, to come naked, to get rid of what we used to know, to let us be taken by the magical maze, fearing not the siren song of languages from the wild, being spoken letting us be spoken by the shifting waters of languages' voices, [that were here] long before us

I saw extraordinarily beautiful pictures of your installation with tiny little animals making up some sort of animal constellation. They look like stars or fireflies, creating a warm texture over the pristine white background, where they seem to float or twinkle. Tell us about how you started this collaborative work with the Qom, about distances and about what does it mean to exhibit them all together, as if they were flocking or herding.

it's so beautiful what you say about figurines of little animals when you name them as stars and fireflies, those also called light bugs turn on and off themselves, they carry 
their own light, they float, they're tiny, and that traveling glow they send out keeps babbling, we might say, an alphabet displaced, tiny little animals met me together with the Qom, when I started to conceive my exhibition for Museo de la Memoria in Rosario, curated by María Elena Lucero, the show's red thread was the translation of one of my texts, Ils,

who translates is maestro Arsenio Borges, a great craftsman, he learnt by watching his grandfather who taught him to feel the clay beneath his fingers

as he translated he became identified with the woman who tells the story of her migration to another country, Arsenio wept as he made Ils text his own, a text narrating my journey from Argentina to Paris and the trials and tribulations of standing in a different place, a different language

the translator translates himself and meets his own exodus from Resistencia, Chaco in el impenetrable till Rouillon district, an unprivileged suburban area in Rosario

he told me about the many kilometers he walked to settle down in poor city suburbs, driven away by the drying cropland, scarcity of food, I understand as he talks that a new translation is needed, one beyond written language

4 I translate into craftsmanship, which is a record of everyday history written down in lowercase letters, written in daily life, baking among dresses, utensils, kitchen, toys, an oral language, like the Qom original language,

709 meaning the $709 \mathrm{~km}$ Arsenio walked until he arrived at Rosario, each little animal meaning $1 \mathrm{~km}$, modeled from clay, baked and unpainted,

the space hosting this work is el Centro del Obrador, in Rouillon district, the neighborhood where part of the community lives; the Centro coordinator, Mariela Mangiaterra, hosted as a link between my proposal and the group, it was discussed at a meeting, why 709 little animals, people emoted, price was set by the craftspeople that made them, inflation increased, and this was taken into account for the final payment, a bond of trust was established, the work is the sum of the production process out of which it came into existence,

935 little animals were produced for the show Translating la impenetrable, matching the number of Km between Resistencia (Chaco) and Buenos Aires,

they glimmer against the background of a white plane, expanding across the surface, as letters, or signs, a clay alphabet put together into a discourse conveying animated energy, shining their own light, rhythmically, like fireflies, babbling out a completely new language that is being created on the spot, for each one's every tiny little light adds to an open geography, one speaking the ancient language of a free land being 


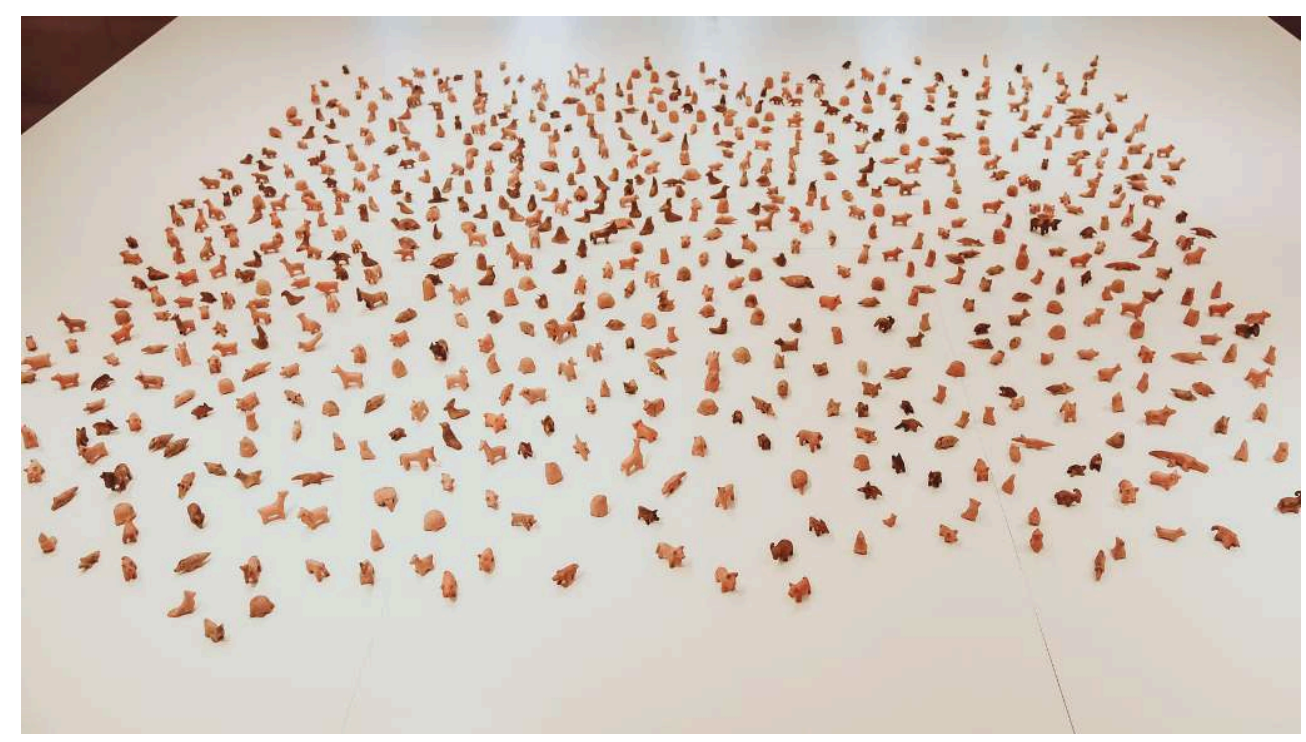

Julieta Hanono, Animalitos / La manada, 2018

109 I enjoy watching your tiny little animals. They provide my eye with two ways of pleasure. On the one hand, there's a sense of herding about them, which make up together some sort of grisaille. On the other hand, I like to stop and watch them one by one, observing their differences, guessing at or finding out which animal each one represents. You can stay there watching them for a long time. I find it interesting that their number is used to measure distance. And I wonder, in these times of discussion about the post-human, about feminism introducing issues related to Anthropocene, [current] epoch when man decides Earth's transformations, even its destruction, what extra meaning there is to cluttering a surface with animal wildlife? I think about [the possibility of] leveling down or even abolishing the human as a measurement parameter for distances or as an agent setting them through human measuring devices. It's an animal measure here. Have you given a thought to these possible interpretations and to their connections with contemporary feminism, one entailing to expose not only violence against women, but the world's seemingly irrevocable fate of destruction at the present moment of global capitalism? The female is what resists the plundering of Earth's natural resources (aggravated by the authoritarianism of new leaders such as Trump or Bolsonaro), the animal as an affective parameter debunking the human from hierarchic center. What do you think about these relations, which may fit or not how you thought up this little clay jungle?

110 your questions open [new meanings], as I answer to you the red thread of my work keeps unfolding

111 the clay jungle is an invocation, no little animal was invented from my imagination, each figurine carries the load of the longing to bring it back; Arsenio and her compañera Clorinda, a craftsperson herself too, working side by side, they edit each other's sculptures as they work, they insist their modeled little animals are near extinction, and they share the load, carrying a vestige of what is being lost, and in the same way their precious little animals testify, having both witnessed days long gone, those of their early youth, exiled now from the abundance of the wilderness to the scarcity of the slums, 
this territory en motion, from a certain point of view, stands for and speaks up for what is being destroyed, but from a different viewpoint it can also be interpreted as the apparition of a memory, exceeding the notion of vestige, becoming an invocation,

the herd of little animals articulates a discourse from another worldview, from a world untamed by the invisible hand (Adam Smith) of market-centered global capitalism; theirs is a discourse where every category of the living, vegetal, animal, human are leveled up, mixed together

in Qom weltanschauung there are no hierarchies between the notions of human and animal, Qom people creation myth is drawn by that dual identity,

When Kharta created the world there was no cold, nor disease, nor death, nor hunger. He just created men, and as they were immortal they had no need to have children. These men were half human and half animals. They had feathers and fur on their bodies and claws in their hands and feet, some could even fly. They lived happily hunting, fishing and gathering, the world had been created for them and men and nature were one...

only the women are complete, star women (see how nicely this fits what we have been talking about, when you compare the little animals to little stars)

...In those early days, from time to time, stars came from the sky down in chaguar fiber strings to steal food from men. Such stars were white, radiant and in the shape of women. Elé saw them descend down the strings and as they were very pretty he tried to take one of them, but these women were very powerful and the parrot man suffered injuries in his mouth, so he partly lost his ability to speak. As he lay on the ground in pain, he watched as women swallowed their food from above and below, for they also had teeth in their vaginas...

that which embodies the female is powerful

...Chiquii summoned a meeting; they deliberated lengthily and decided to send the flea man flying beyond the sea for a solution. When he came back he brought along the knowledge of fire, until then men ate raw food. He also brought wind, cold, disease and death.

the female inspires awe, the feeling that it must be tamed, vaginas' teeth broken; meeting the other ensures the end of eternity and the beginning of human life,

...Men began to sing the day, a strong wind came and it was very cold. Women, who were naked, started to shiver and came closer to the fire. Men then threw into the fire a magic stone that exploded and entering inside all women broke their teeth below. This was how animal men mated with star women and their children are Toba people today.

here the female is whole, they're near-godly, they stand up to the animal-men, this brings into consideration a big difference with Western Judaeo-Christian idea that woman was created from a part of man, in Lacan's terms, if the notion of phallus is an illusion and phallus is actually shared, we might say women, from their very origins, share the same attribute with men, and men, in order to meet them, must give up their animal side, and this can be interpreted as letting go a certain kind of manliness,

before colonization, the Qom organized themselves through councils of elders, who were women and men, and lived in gender equality; after evangelization, priests and ministers, who were representatives of monotheistic religion, appointed themselves as their community leaders, bringing along a male-centered, patriarchal model, in an attempt to bring down this ancestral system

Ruperta, a representative of the Qom, defines herself as a warrior woman, legendary warrior women were the amazons, a word that comes from ancient Greek $\dot{\alpha} \mu \alpha \zeta \dot{\omega} v$, 
breastless, the half-true, half imaginary story tells they would cut off their right breast so they could hold the bow,

Ruperta tells me she doesn't like (evangelical) ministers, they make women wear long skirts and prevent them from speaking

Already during the discovery of the Americas, Columbus tells about an island inhabited by women we can imagine as resembling them; priest Gaspar de Carvajal, chronicler of the expedition lead by Spanish conquistador Francisco de Orellana in 1542, writes how warrior women shot arrows and darts from their blowpipes at them from across the river, and as a consequence of the impact of his story, said river was renamed Amazon or Amazon River, here is an excerpt from his recollection

...Known be they are subjects and vassals to the Amazons, and once informed of our arrival, requested their succor and about ten or twelve came, these we saw, fighting ahead of all Indians as women captains and fought so bravely that Indians dared not turn back...

Bolsonaro tries to forget that the amazons exists, when he plunders what he considers his own, the Amazon, and I wonder if the wish to subdue them remains intact in the minds of bossy males,

little animals herding, a territory of pure gratuitous sensitive living, where everything is mingled together at the same level, different yet pulsing as one heartbeat, building an imaginary dam to stop invader policies that are destroying the planet, fireflies, star women, amazons, she-shamans, a visual discourse written in baked clay letters, feminist, present

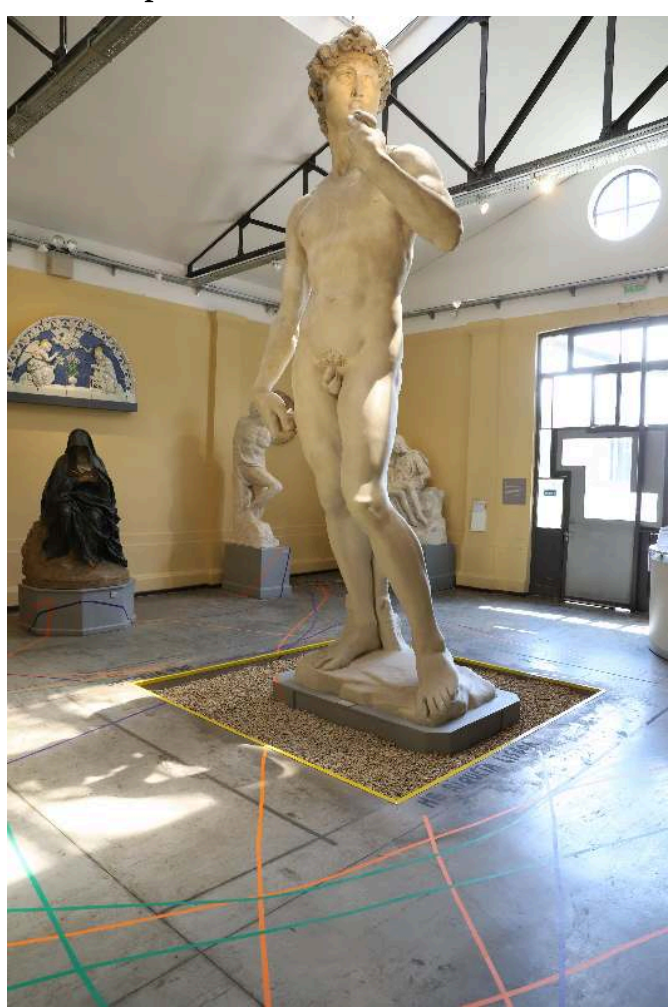

Julieta Hanono, Cosmología de las poetas, 2018 al presente 


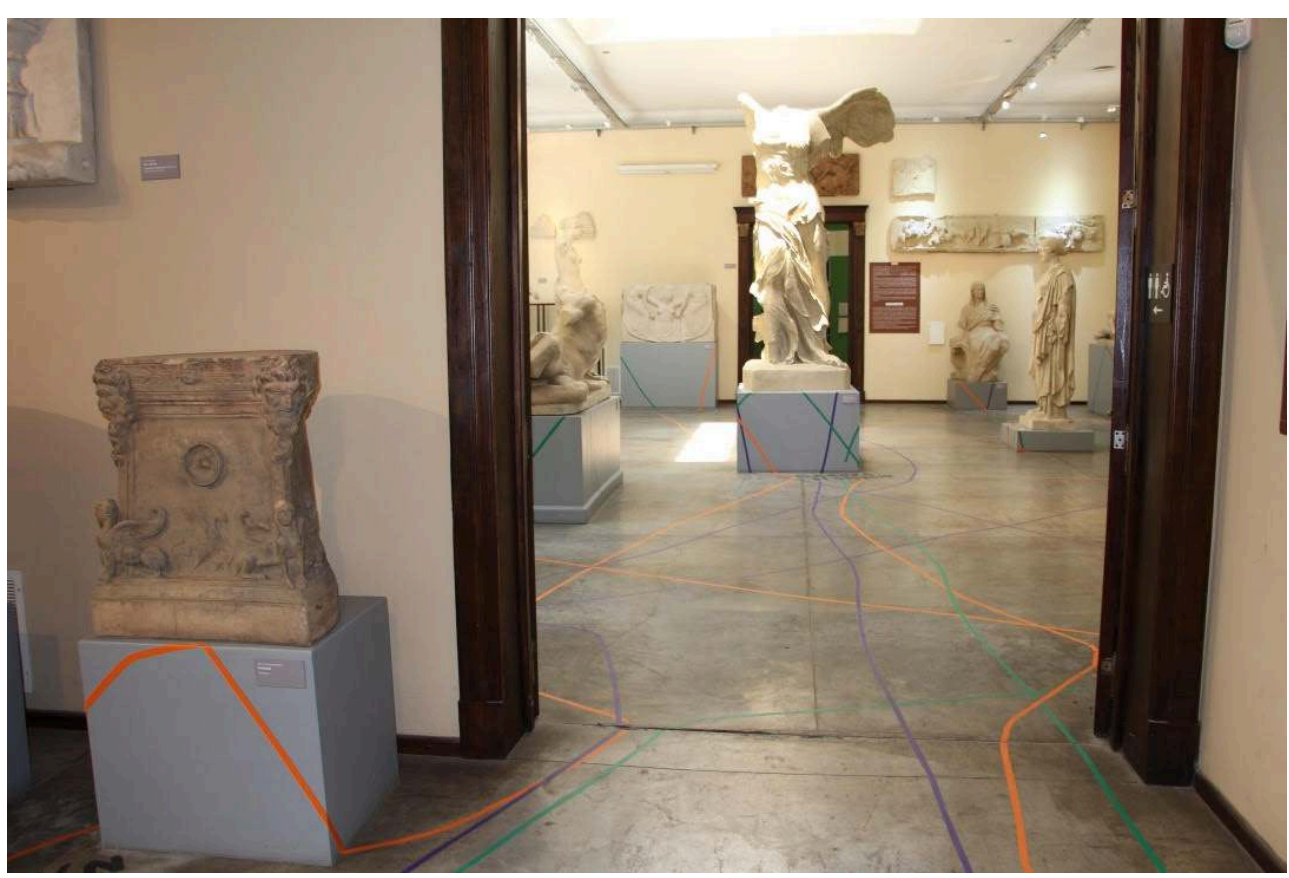

Julieta Hanono, Cosmología de las poetas, 2018 al presente

Feminism shows up in your exhibition as a file displayed across the floor, when you draw a map of poets, a cosmology as you call it, resulting from the interaction among their names. And you're doing all this in colors which are meaningful regarding the feminist struggle that took to the streets in recent years: purple, traditionally linked with feminisms; green, a color associated with the campaign to legalize voluntary interruption of pregnancy; orange, which represents the separation of church and state, a safety bolt necessary to stop church from exerting such power over civil society that dogmas regulating believers' lives are enforced across the whole community. Dogma enforcement neglects the fact that clandestine abortions, which occur in spite of law and church across all social classes, have a particular impact on the poor, because cheap abortions are performed in unsafe conditions that put to risk these women's lives. Why, then, knot together these colors with poetry? Is this an intended relationship between politics and poetics? Why have you chosen the women authors you name here?

constellations guided sailors in days of old as they sailed across the map of the world; my poets are a cosmology of consciousness pulsing and shining, woven from the Museum floor among sculpture casts (representatives of an exclusively male gaze), the cosmology of their intertwined names rises and overflows, challenging and questioning years of history, it's la impenetrable freely climbing, language subversion in full glow

I name them as poets, I could call them fireflies, stars, mermaids, she-shamans or sorcerers, with their words invoking spirits and forces, radiating the light of questions, opening up the game of language, de-constructing the way male history has conceived writing, rendering it untranslatable, mysterious, that is why we can't afford not to knot poetry and politics together

I shall quote only a few of them, unfolding the intentions of this map to the stars, the most remote of them being Sor Juana Inés de la Cruz, an expression of independence when she decides over her own life choices, entering the convent so as to make true 
her wish to be a woman who writes; or Alfonsina Storni, exposing in her poetry the male chauvinism of her times and trespassing social norms in her personal existence; Violeta Parra a nomad, compiling folk songs from the lore of her homeland, listening to the most fragile voice, the voice of the poor; Susana Thénon in her dual identity within language, translating into French, advancing feminism, together with Alejandra Pizarnik writing her feminine love for women between Buenos Aires and Paris,

if the least cared for, the most unprivileged, suffer the hardship and injustice of clandestine abortion, then linking women poets together, using the emblematic colors of feminism, brings to the present the vertigo of her texts, restores their actuality, poetry lays no more in the limbo of the poeticizing, is no longer a metaphor, it becomes concrete; to de-poeticize poetry is to make out of it, as poet Gabriel Celaya says, $a$ weapon loaded with future

in poetry invention, language subversion, what speaks is only what's written, it is the body who speaks; I have chosen these few poets, a handful of women writing from their bodies, constructed by this relationship between writing and living, translators and interpreters of what other women lived

colored ribbons that link them together weave a fabric revealing their secret and invisible connection; history is rewritten, the personal history of each poet's poetry voice and everyone's is joined together in the sorority of their intent, and in a hostile world that will not listen, they open up into another history of struggles, from the ground to the sky, the voices of female power, in a choir of written thought, rising

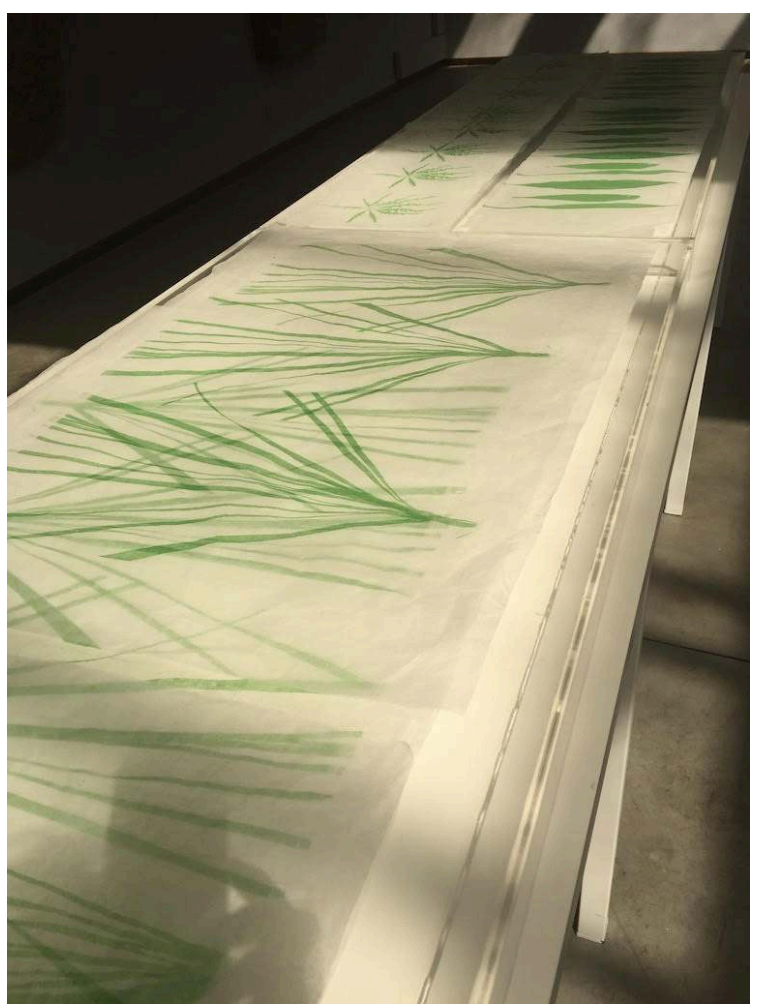

Julieta Hanono, Ruperta's magical garden, 2019

Ruperta's magical garden sounds so beautiful. I know you build upon the translocation of vegetal species, plants, flowers that Ruperta carried from el Impenetrable, where she lived, to Rosario, where she was displaced to. There is a 
poignant poetry to this voyage and it makes her Diaspora and alien status sweet. That garden is like a warm blanket where she comprises the wilderness environment into her garden, almost a memorial to nature, an affectionate memorial keeping her company and every day reminding her where she comes from. We may think about the post-human also here. I saw the pictures you took in Ruperta's garden and imagine how that herbarium might look once it's printed from lithographic plates on translucent paper. We discussed the idea of placing these sheet in glass display cases lit from below, with walking space between them, at the prehispanic casts' room. Please tell us a little bit about this artwork and what it means in the context of the ensemble you shall arrange in all rooms. Ruperta says 'I live in Miraflores', she says so from her garden, in Rouillon district, a suburb in Rosario, surrounded by her plants she brought from her wilderness, she is and stays in both places and that garden stands for her dual identity,

Ruperta carries her green thumb gift along with her, she grows vegetable gardens for the community, which she shows to me when she invites me to her garden, where there are also flowerpots hanging from the branches of her tree where birds come to sing and its friend Roberta says it weeps in the morning, when it listens to them

she listens to the wilderness and the wilderness is she, and the herbarium is a way to put forth the idea that everything in sensitive life is mingled together, everything is animated and her tree is as magical as everything about her

141 but she is a shaman too, and the title magical garden is by no means meaningless, it is the song of the voices of every spirit that animate each plant so each one carries the memory and history of their language, her gesture of bringing them here, so as to surround herself with them, dispels distance, and memory comes alive

142 I might have cut the plants, dry them and produce a herbarium in the classical sense, but to transfer is also another way to translate, to create language at a new level, a technique bringing me back to my earliest artwork, to engraving technique

143 I wanted a quality of paper that brought to me a feeling as close as possible to the vegetal, to nature's fiber, so I chose thin sheets of Japanese paper, as thin as plant leaves,

144 the protective glass display cases enclosing them build up an architecture of the vegetal record, encased in lit up blocks, opening our eyes to the delicacy of detail in their stark, fragile, tough nervations, pulsing with the structure of the vegetal itself, her garden is made up of plants for healing and protection, such as the Mapic which is now a tree and its pods have huge nutrient properties, or the Adelia which is customarily placed at the entrance of the house to welcome the guests in the right way magical garden is more than just a piece of wilderness which travelled from Miraflores to the suburbs of Rosario, it is a tangible witness to the dual identity of her heart, standing with a foot on each side, and that garden is tele-ported into the Museum from other ways, it is deconstructed since the transformation of plant matter into paper transfer, and reconstructed to elaborate the herbarium in showcases, the herbarium, pulsing with animated spirits, paints Ruperta's self-portrait: the plants she has chosen treasure the secrets of her magic 


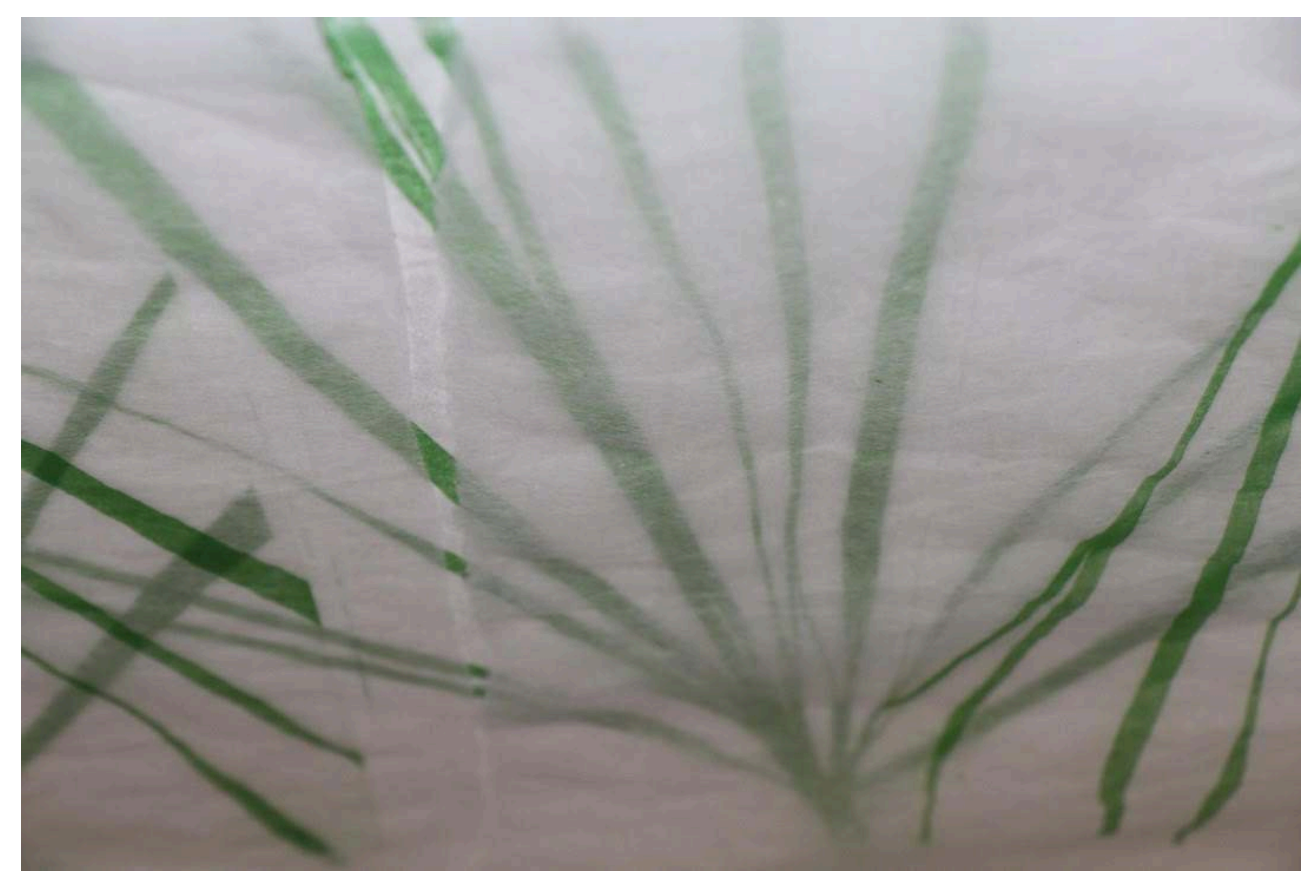

Julieta Hanono, Ruperta's magical garden, 2018

I guess it is also in the prehispanic casts' room where you're installing the "A hood made of clouds" series of posters printed in white on white. Inevitably comes to my mind the echo of Malevich or Argentinean [artist] Lea Lublin, who, just like you, lived in Paris. Both made "white on white" pieces. Why is this print artwork here? What role does language play in it? Which words have you printed?

...when $i$ arrived at Paris, it was mist, they wanted to show me the city and took me to Pigalle... when I had just arrived, I was shrouded in ghosts of the past, as one who stands in a cliff above the sea and if jumps may fly or fall, this is how I felt when I met those works by Lea Lublin, white images against a white background, white on white, healing shapes at that time of dismay,

151 I stood in front of them and they fascinated me, they were a mirror, I found out what was going on inside of me, my being being reflected, to start anew from scratch, to be a page that seems blank but is already written on, in invisible paint, Lea was asking me to look, to get in there with my eyes so as to reveal their secret discourse when Macbal, Museé de la Seine et Marne, suggested me to make a print for woman's day, I thought about an all-encompassing sentiment that might convey a wide-range notion of feminism, and found this quote from the preface to Capital book 1 by Karl Marx,

"Perseus wore a magic cap [a hood made of clouds, in the Spanish version] that the monsters he hunted down might not see him. We draw the magic cap down over eyes and ears as make-believe that there are no monsters!"

the text is enigmatic, we can interpret it from the point of view of a purely political vindication but also from a feminist point of view, monsters are still there when women are imprisoned for aborting,

the very way the quote's discourse is articulated led me to think of it in white, how to become invisible ourselves so we can defeat monsters, how could I become visible from 
my invisibility, so that viewers re-appropriate my body?, an artist feeds his or her body to the other, revealing his or her discourse, but also her or his corporeality as well,

so, they're posters and anti-posters at once, they don't display anything straightaway, their intention is not to communicate, (if we think on what Foucault says, about communication as an instrument of dominant words) white on white, so that an effort is necessary in order to reveal discourse, discourse is not a given, it's a question, a desire relationship is established, whoever wishes to read it involves his or herself in the very statement put forth by the text she or he is reading in he first place

I made it in French, but una capucha de nubes (a hood made of clouds) is being translated to all languages it travels along, which is a way to appropriate it, from each language, at every new place, the technique to make the poster is different, which means another language is another translation, another technique,

Sail on! The white, free abyss, the infinite is ahead of you!

Kasimir Malevich, On cubism and futurism to suprematism. New painterly realism, 1916.

the body, standing before the unseen, gaze as it matches light makes the unseen visible, and so we are enabled to crack up secret discourse, and as it reveals, we understand word is action, verb, written text writes on over our bodies

Let's talk about film-text Wealth of nations, also featured at la Cárcova exhibition. You revisit here a 1776 text by Adam Smith with the same title. I understand you take it as a potential departure point from the global economic order, along with English market-centeredness and the notion of an economic order articulated by the notion of Commonwealth, a new rhetoric enounced by a commercial colonialism which drew maps overlapping the colonial order based on the administrative and control systems which regulated, for instance, commerce between colonies and the Spanish crown. Year 1776 is, if I recall correctly, when Bourbon reforms are instituted, during the reign of Charles III, establishing new viceroyalties and a looser communication system than the one regulating acknowledgment of only two legal ports, Veracruz and el Callao. Everything suggests that the rules of the game that governed the notion of 'world' were being changed at that time. You selected chapter "Colonies" for this film, running [it onscreen] upwards, like film credits. And you match the text with footage of a sunset at the Iguazú waterfalls. Sun is blotted out into the horizon, downwards. Why did you establish this precise relation between image and text? Which is the political meaning this lingering time when image and text go by intends to activate?

162 I was divorcing from my husband, I traveled with my youngest son, our room had a view right in front of the falls, a colonial hotel within the Iguazú waterfalls park

163 I got off with the camera, I stood facing the falls, the park was closing, there was almost no one left, tour buses were leaving, and I stood alone facing the setting sun, wrapped in light and sound, it was all so intense I set the camera at a ridge for a front view so as to capture what I was feeling, and let it roll and stayed beside it watching the sun set among clouds of steam and rainbows, birds singing animals making noises insects buzzing, the smell of plants all that vitality lit up

164 I recorded inside of me the sequence of that time as a time of change within me, my body was the South, the timing of sunset let me think about all the span of my long journey between Argentina and Paris 

your answers and sending new questions. I restrained my second nature impulse, as a writer an editor in Spanish, to correct or edit your answers. You begin all your sentences in lower case letters; commas, accent marks, periods, full stops are missing. There are grammar inconsistencies. I can clearly sense those 
dislodging points convey a poetic feeling. Discussion topic today is whether I shall edit your texts or not. I guess I won't. Let us talk about then, as an ending to this interview, the meaning you give to that constant slipping among written words.

I usually agree to correct certain mistakes (accent marks or commas missing), but I kind of refuse to correct my syntax or style, for what might be read as an error or misspelling is, actually, the voluntary reflection of a way to name a place, my language

removing capital letters from the beginning of each paragraph is a way to signal that what I write as part of an infinite, one plus one plus one and so on, nothing is the head to a hierarchy, for I regard both my texts and artwork as fragments, and fragments are all pieces of something, they have no beginning or end, they're part of the unfolding of the same

I leave blanks and use commas, so that such blanks stand for the void, which can be felt as breathing, as a pause,

I compose both my texts and my artwork from a spatial concept, as if I was sculpting, both my texts and my visual pieces can be read as music scores, or sculptures, through which I translate and interpret this huge puzzle I am immersed in since before I was born, and if I write in first person it is because I am assessing, giving testimony

\section{ABSTRACTS}

This interview with artist Julieta Hanono was conducted in 2019 on the occasion of her exhibition Traducir la impenetrable (Translate the Impenetrable) at the Museo de la Cárcova in Buenos Aires. Julieta was born in Rosario, Argentina, and lives in Paris. As an adolescent, she was arresteddisappeared by Argentine military forces during the dictatorship. She studied art and philosophy first in Argentina and then in France. Her film El pozo (The Ditch) addresses her experience in prison. Her recent work has focused on the problem of translation.

Esta entrevista con la artista Julieta Hanono se realizó durante de 2019 en ocasión de su exposición Traducir la impenetrable, en el Museo de la Cárcova, en Buenos Aires. Julieta nació en Rosario, Argentina, y vive París. Durante su adolescencia estuvo detenida-desaparecida por la dictadura militar argentina. Estudió arte y filosofía en Argentina y luego en Francia. Su film El pozo remite a su experiencia en prisión. Durante los últimos años su trabajo se ha centrado en el tema de la traducción.

Cette entrevue avec l'artiste Julieta Hanono a été réalisée en 2019 à l'occasion de son exposition Traduire l'impenétráble, au musée de Cárcova, Buenos Aires. Julieta est née à Rosario, en Argentine, et vit à Paris. Pendant son adolescence, elle a été arrêtée par la dictature militaire argentine et disparue. Elle a étudié l'art et la philosophie en Argentine puis en France. Son film El pozo (Le Trou) fait référence à son expérience en prison. Au cours des dernières années, son travail s'est concentré sur le sujet de la traduction. 
INDEX

Mots-clés: Julieta Hanono; Argentine; El pozo; traduction.

Palabras claves: Julieta Hanono; Argentina; El pozo; traducción.

Keywords: Julieta Hanono; Argentina; El pozo; translation.

\section{AUTHORS}

\section{ANDREA GIUNTA}

Andrea Giunta is a Doctor of Philosophy and a professor of Latin American and modern/ contemporary art at the Universidad de Buenos Aires School of Philosophy and Letters. She is a main researcher at the CONICET and the curator of Biennial 12, Porto Alegre, Brazil, 2020. 